Volume 5

$10-2020$

\title{
A Tribute From Robin Morgan: Kate Millett Memorial Service
}

Robin Morgan

Follow this and additional works at: https://digitalcommons.uri.edu/dignity

\section{Recommended Citation}

Morgan, Robin (2020) "A Tribute From Robin Morgan: Kate Millett Memorial Service," Dignity: A Journal of Analysis of Exploitation and Violence: Vol. 5: Iss. 2, Article 16. https://doi.org/10.23860/ dignity.2020.05.02.16

This Kate Millett Memorial Issue is brought to you for free and open access by DigitalCommons@URI. It has been accepted for inclusion in Dignity: A Journal of Analysis of Exploitation and Violence by an authorized editor of DigitalCommons@URI. For more information, please contact digitalcommons-group@uri.edu. 


\title{
A Tribute From Robin Morgan: Kate Millett Memorial Service
}

\author{
Abstract \\ Turner. \\ Creative Commons License \\ (c) $(i) \Theta \Theta$
}

A Tribute From Robin Morgan includes the text of her tribute and a video. The tribute is read by Kathleen

This work is licensed under a Creative Commons Attribution-Noncommercial-No Derivative Works 4.0 License. 


\section{DIGNITY}

Volume 5, Issue 2, Article 16, 2020
A JOURNAL ON

SEXUAL EXPLOITATION

AND VIOLENCE

\title{
A TRIBUTE FROM ROBIN MORGAN: KATE MILLETT MEMORIAL SERVICE
}

\author{
Robin Morgan (Read by Kathleen Turner) \\ Feminist poet and author, USA
}

$\mathrm{I}$

'M DEEPLY SORRY I CAN'T BE THERE TODAY with you all, but the fine actor Kathleen Turner is graciously giving voice to these words, excerpted from a piece I wrote after the loss of Kate, called "Dancing into Shadow." You can find the piece online.

We met in the late 1960s, amid the furious budding of contemporary feminism. I'd heard about an interesting dissertation dealing with sexism and literature being written by some feminist artist newly back from years living in Japan, and I tracked her down. Warm but shy, she let me read her dissertation, and I convinced her to let me publish an excerpt from it in an anthology I was compiling-a little book called Sisterhood Is Powerful. "But it's just a dissertation," she shrugged, "Only academics will be interested, not the general public." Nevertheless, the inclusion of that excerpt triggered editors' interest in that dissertation - which became a little book called Sexual Politics.

Both activists, we ran into one another at demonstrations and meetings, and became friends-but friends in a way different from other political friendships, because both of us were also artists: Kate a sculptor and painter, me a poet and writer. This was the constant thread that would run through decades of our friendship. Even when we quarreled or were on the outs with one another, Kate always showed up at my poetry readings and I always showed up at her art exhibits.

Yet Kate was also with me on the boardwalk in Atlantic City at that first Miss America Pageant Protest in 1968. She then volunteered her Bowery loft for a dance to raise funds for lawyers' fees, since some of our women had been arrested in Atlantic City. For years after, we laughed ruefully about what happened: hundreds of people showed up and danced long and energetically, literally breaking her floorwhich then required serious shoring up so as not to collapse the whole building, and the bail money ultimately went (at least a partial way!) toward that.

Kate and I differed on how we handled that fame/notoriety, as well as the rare moment of solvency that followed. When Sisterhood Is Powerful took off like a rocket, I started the first feminist grant-giving foundation-The Sisterhood Is Powerful Fund [SIP]-and poured the royalties into it, so the money would build the movement, create rape-crisis centers, battery shelters, feminist periodicals, and so forth. It never occurred to me to do otherwise. Kate, who proudly acknowledged she was at heart an Irish peasant, scolded me "Robin. Don't. Be.A. Fool." She urged me to do what she was doing-use the royalties to buy real estate. She bought a farm in upstate New York for her own use and delight, eventually to become a 
women's art colony. Kate was probably right. I sometimes had trouble paying my electric bill, but didn't touch the royalties. Nevertheless, The SIP Fund was depleted in time; the farm will last, part of Kate's legacy.

It became a legend, an Amazonian arts colony that grew holiday trees to help sustain itself. And Kate, ever the true bohemian, could be found on a Manhattan street corner at Christmas time, selling her trees to people totally unaware of their mittened saleswoman's identity. The farm was where Kate wrote her books and made her art-the large "Fat Ladies" statues, the ink-on-paper drawings, the silkscreen works she devised so that she could produce inexpensive prints average folks could afford, since she felt strongly that everyone should be able to have artreal, original art-in their homes. The farm was where friends came and went, especially in late August to celebrate Obon, the Japanese festival of the dead, of the ancestors. The Obon feast was observed by lighting candles inside small paper bags, makeshift lanterns, then setting them adrift on tiny leaf-and-twig rafts across the pond, where their light floated into darkness.

Kate loved playing hospitable matriarch, and I always felt welcome. When I embarked on hosting a series of home-cooked dinners to bridge artist friends and political friends in Manhattan, Kate was a regular, since she qualified in both categories.

A feminist generation is marching again, this time into shadow. Another generation will march into the sun.

Kate's feminist writing stands tall among work that changed consciousness and saved lives. But to find the friend I'll miss, I look at a large black-ink-on-whitepaper work of hers I have. There are her lyrical, witty, Japanese influenced swoops and dots that gradually register to the eye as a woman's buttock, thigh, vulva, and clitoris. Like its maker, this spare yet lush exuberance of flesh exposes itself with such sensual purity it shocks.

To find the friend I miss, I look for the flame of her flickering in a soft summer wind, as it dances across dark waters into the night.

\section{AUTHOR BIOGRAPHY}

Robin Morgan is a feminist poet and author. https://www.robinmorgan.net/

\section{RECOMMENDED CITATION}

Morgan, Robin. (2020). A tribute from Robin Morgan: Kate Millett memorial service.

Dignity: A Journal of Sexual Exploitation and Violence. Vol. 5, Issue 2, Article 16.

https://doi.org/10.23860/dignity.2020.05.02.16 Available at

http://digitalcommons.uri.edu/dignity/vol5/iss2/16. 